\title{
The Regional (State Level) Importance of the Agribusiness GDP in the Brazilian Economy
}

\author{
Joaquim J.M. Guilhoto \\ Department of Economics - FEA \\ University of São Paulo, São Paulo, Brazil \\ Regional Economics Applications Laboratory (REAL) at \\ The University of Illinois at Urbana-Champaign, USA \\ CNPq Scholar \\ e-mail: guilhoto@usp.br
}

\section{ÁREA 5: Economia Regional e Economia Agrícola}

\begin{abstract}
Following Furtuoso and Guilhoto (2003) the GDP of the Brazilian Agribusiness is estimated to be around $27 \%$ of the Brazilian GDP in 2000, and the latest numbers show that it could be reaching $30 \%$ of the Brazilian GDP in 2003. Despite its importance for the Brazilian economy as a whole, the size of the Brazilian territory and the regional differences draws attention for the fact that the importance of the agribusiness is not uniform over the Brazilian regions, and if the agribusiness is also divided into its four components, i.e., a) inputs to agriculture; b) agriculture; c) agriculture based industry; and d) final distribution, the differences are even bigger. In this paper it is made a study of the importance of the agribusiness for the 27 states of the Brazilian economy, taking into consideration its four components. The analysis is conduct for the year of 1999 using an interregional input-output system constructed for the Brazilian economy by Guilhoto et al. (2004).
\end{abstract}

Key Words: Brazil, Agribusiness, Regional Aspects, Input-Output.

JEL Classification: R15, Q10, O13 


\section{RESUMO}

Seguindo Furtuoso e Guilhoto (2003) o PIB do Agronegócio brasileiro em 2000 correspondeu a aproximadamente $27 \%$ do PIB do Brasil, e as últimas estimativas mostram que este número pode estar chegando a 30\% do PIB em 2003. Apesar da sua importância para a economia Brasileira como um todo, o tamanho do território brasileiro e as suas diferenças regionais chamam atenção para $o$ fato de que a importância do agronegócio não é uniforme em todas as regiões brasileiras, e se o agronegócio é dividido nos seus quatro componentes, isto é, a) insumos para a agricultura; b) agricultura; c) indústria de base agrícola; e d) distribuição final, as diferenças são ainda maiores. Neste artigo é feito um estudo da importância do agronegócio para os 27 estados da economia brasileira, levando em consideração os seus quatro componentes. A análise é feita para o ano de 1999 e se utiliza de um sistema interregional de insumo-produto construído para a economia brasileira por Guilhoto et al. (2004).

Palavras Chaves: Brasil, Agronegócio, Aspectos Regionais, Insumo Produto

Código JEL: R15, Q10, O13 


\section{INTRODUCTION}

With the post-war worldwide technological revolution of agriculture, the farming activities underwent a large expansion and increasing specialization, decisively influenced by the economical development and growing urbanization. Such process basically imposed a new agricultural order in which the modern farmer is an expert involved with cultivation and animal breeding operations thus transferring the functions of storing, processing and distribution of vegetal/animal products as well as the supply of input and production factors to organizations other than the farm.

Previously focusing on self-sufficiency, agriculture was updated and introduced into the market economy constituting new links or segments to the feeding system. Basically this process resulted in the structuring of a modern industrial park providing capital goods and input for that area. On the other hand, complex storing, transportation, processing, industrialization and distribution networks were formed

As a result of such phenomenon, the traditional economy concept that classifies the different activities as "primary, secondary and tertiary" sectors as separate and not integrated led to an analysis focusing on an interlinked system of production, processing and distribution of farming-originated products - the Agribusiness.

The pioneering academic contribution to quantify such conceptual approach was done by Davis \& Goldberg (1957) when they created the term Agribusiness. Making use of input-output matrix techniques devebped by Wassily Leontief (Leontief, 1951), the authors studied the transformations and restructuring of agriculture. By analyzing the problems related to the agricultural sector of the economy they stated that these were much more complex and not limited to an ordinary rural activity. That explains the need of dealing with agricultural problems under a systemic focus (Agribusiness) instead of a static one (agriculture).

Such expansion and specialization process of the agriculture is known to have occurred homogeneously in all regions of the planet, for it depends on the economic and social stage of development of each one of them. Namely, the participation and interaction of the agents - farmers, input suppliers and production factors, processors and distributors - occurred in different degrees in the various levels of the agriculturalfeeding system (Pinazza \& Araújo, 1993).

This worldwide transformation process also occurred in the Brazilian agriculture system with the agriculture and the stock raising activities being redirected, updated and integrated into the market.

In view of these considerations, it is clear that the integration between agriculture and industry implies a real restructuring of the rural sector, establishing deep technological, productive, financial and business relationships with the other economy activities.

With the above in mind, the next section will present the methodology developed to estimate the agribusiness in the Brazilian economy. Section 3 will present the results for the Brazilian economy with special reference to the importance of the agribusiness in the 27 Brazilian states, and it is also made a comparison with the importance that the 
agribusiness has in a selected group of countries, in the Americas and Europe. The final remarks are made in the last section.

\section{METHODOLOGY TO MEASURE THE A GRIBUSINESS SYSTEM}

This section will make a presentation of the methodology used to measure the Agribusiness system in Brazil, further methodological discussions on the estimation of the Agribusiness Complex can be found on the works of Furtuoso (1998), Furtuoso, Barros and Guilhoto (1998), Guilhoto, Furtuoso, and Barros (2000), and Furtuoso and Guilhoto (2003).

The total GDP value of the Agribusiness can also be divided into 4 aggre gates: I) inputs; II) the sector itself; III) industrial processing; and IV) distribution and services.

The procedure adopted to estimate the Agribusiness GDP is through the scope of the Product, i.e., by estimating the value added at market prices, and, it is tanking into consideration the methodology presented by the System of National Accounts defined by the United Nations (SNA, 1993), where the input output matrices are integrated in this system.

The value added at market prices is given by the sum of the value added at basic prices with indirect net taxes less the financial dummy, resulting in:

$$
V A_{M P}=V A_{B P}+I N T-F D u
$$

where:

$$
\begin{aligned}
& V A_{M P}=\text { Value added at market prices } \\
& V A_{B P}=\text { Value added at basic prices } \\
& I N T=\text { Indirect net taxes } \\
& F D u=\text { Financial dummy }
\end{aligned}
$$

To estimate the GDP of Aggregate I (input for vegetal and animal production) one uses the information available in the input-output tables regarding the input values acquired by the Vegetal and Animal sectors. The columns with input values are multiplied by the respective coefficient of value added $\left(C V A_{i}\right)$.

The Coefficients of the Value Added for each sector $\left(C V A_{i}\right)$ are obtained by dividing the Value Added at Market Prices $\left(V A_{M P}\right)$ of a given sector by its respective output $\left(X_{i}\right)$, i.e.,

$$
C V A_{i}=\frac{V A_{M P}}{X_{i}}
$$

Thus, the double-counting issue presented by previous Agribusiness GDP estimates when input values were considered, instead of the value added effectively generated by it, is eliminated. In that sense the GDP of the Aggregate I is given by: 


$$
G D P_{I}=\sum_{i=1}^{n} z_{i k} * C V A_{i}
$$

$i=1,2, \ldots, \mathrm{n}$ are the economic sectors

where:

$G D P_{I}=$ GDP of aggregate $\mathrm{I}$ (inputs)

$z_{i k}=$ total input value of sector $i$ to the agricultural sector $k$

$C V A_{i}=$ value added coefficient of sector $i$

The estimates for the Aggregate II (the sector itself) considers the value added generated by the respective sectors, subtracting the values used as input from the value added of these sectors, thus the double-counting issue found in the previous Agribusiness GDP estimates for the Brazilian economy is again eliminated. Then one has:

$$
G D P_{I I}=V A_{M P_{k}}-z_{k k} * C V A_{k}
$$

where:

$$
G D P_{I I}=\text { GDP of aggregate II }
$$

and the other variables are as previously defined.

To define the composition of the Aggregate III (agriculture based industries) several indicators were adopted as for instance: a) the main demanding sectors of agricultural products obtained by input-output matrix estimation; b) the share of agricultural input in the intermediate consumption the agroindustrial sectors; and c) the economic activities carrying out the first, second and third transformation of agricultural raw materials.

In the estimation of Aggregate III (Agriculture Based Industries) one adopted the summation of the value added generated by the agroindustrial sectors subtracted from the value added of these sectors that have been used as input in the Aggregate II. As previously mentioned, this subtraction is done to eliminate the double-counting found in previous Agribusiness GDP estimates, as so, one has that:

$$
G D P_{I I I}=\sum_{q}\left(V A_{M P_{q}}-z_{q k} * C V A_{q}\right)
$$

where:

$$
G D P_{I I I}=\mathrm{GDP} \text { of aggregate III }
$$

and the other variables are as previously defined. 
In the case of Aggregate IV, regarding the Final Distribution, one considers the aggregated value of the Transportation, Commerce and Service sectors. Out of the total value obtained for these sectors only the part corresponding to the share of the agricultural and agroindustrial products is designated to the Agribusiness in the final

product demand. The approach adopted in the estimation of the final distribution value of the industrial agribusiness can be represented by:

$$
\begin{array}{r}
G F D-I N T_{F D}-I P_{E D}=D F D \\
V A T_{M P}+V A C_{M P}+V A S_{M P}=T M \\
G D P_{I V}=T M * \frac{F D_{k}+\sum_{q \in k} F D_{q}}{D F D}
\end{array}
$$

where:

$G F D=$ global final demand

$I N T_{F D}=$ indirect net taxes paid by the final demand

$I P_{F D}=$ imported products by the final demand

$D F D=$ domestic final demand

$V A T_{M P}=$ value added of the transportation sector at market prices

$V A C_{M P}=$ value added of the commerce sector at market prices

$V A S_{M P}=$ value added of the service sector at market prices

$T M=$ trading margin

$F D_{k}=$ final demand of agriculture

$F D_{q}=$ final demand of the agroindustrial sectors

$G D P_{I V}=$ GDP of aggregate IV

The Agribusiness GDP for each sub-complex is given by the sum of its aggregates as:

$$
G D P_{\text {Agribusiness }}=G D P_{I}+G D P_{I I}+G D P_{I I I}+G D P_{N}
$$

where:

$$
G D P_{\text {Agribu siness }}=\text { Agribusiness GDP }
$$

and the other variables are as previously defined.

\section{THE BRAZILIAN AGRIBUSINESS}

This section will start with an overview of the importance of the agribusiness in selected countries of the Americas and Europe, trying to relate the importance of the agribusiness with the development level in these countries. Then, this study goes down 
to see the importance of the agribusiness in each one the 27 Brazilian states, and once more trying to relate its importance to the development level in each one the Brazilian states. The results for the Brazilian economy are also aggregated at the level of the 5 Brazilian macro regions.

\subsection{Agribusiness in the Americas and Europe}

This section presents an overall view of the agribusiness in the Americas and Europe. Despite the difference in methodologies and the fact that the data is for different years, it is possible to have a general idea for the importance of the agribusiness for each one of the countries presented in Table 1, and relate the agribusiness with the development level in these countries. The data for the European countries is based on van Leeuwen (2000), the one for the American countries is based on IADB (2003), while the data for the Brazilian economy the result of this study, conducted using an interregional input-output system constructed for the Brazilian economy for the year of 1999 by Guilhoto et al. (2004).

From Table 1, using the per capita GNI as a measure of development, it is possible to see that in general as the per capita GNI in a givencountry increases, the share of the agriculture and agribusiness in the economy has a tendency to decline, such that for the countries with a per capita GNI with less than US\$10,000 the average share of a griculture in GDP is $8.33 \%$, with an agribusiness share of $29.68 \%$, for the countries between US\$10,000 and US\$20,000, the average shares are respectively of $5.67 \%$ and $14.77 \%$, and for the countries with a value greater than US\$20,000 the respective average shares are of $2.62 \%$ and $8.83 \%$. On average, for the countries listed into Table 1 , the share of agriculture in GPD is of $5.04 \%$ and the agribusiness has a share of $17.05 \%$.

Of the selected countries, the one s that show the smallest share of the agriculture in the economy are Germany and the United Kingdom (1.3\%), followed by BelgiumLuxembourg and the U.S.A. (1.6\%). On the other extreme, one finds Colombia with an agriculture share of $14.3 \%$ and Costa Rica with a share of $12.80 \%$. This clearly shows that of the selected countries the agriculture sector does not seems to be the driven force of these economies.

However, if one takes the more complete and complex concept of agribusiness it is possible to see that, of the selected countries, the agribusiness can reach a share of almost $35 \%$. It means that one should pay special attention the economic importance of the agriculture in these countries. As a result of that, the multiplier effect of the agriculture in the economy, going to the concept of agribusiness, is between 2.2 and 5.9, with an average of 3.6, meaning that the agriculture power at least is doubled in a given economy.

The results for the Brazilian economy are very close to the ones for the average economy in the countries with less than a GNI per capita income of less than US\$ 10,000 , i.e., for Brazil, the agriculture share is of $7.47 \%$ and the agribusiness share is of $26.58 \%$, with a multiplier power of 3.6. 
Table 1. GNI Per Capita, Agriculture and Agribusiness Shares in Selected Countries

\begin{tabular}{|c|c|c|c|c|c|}
\hline Country & $\begin{array}{c}\text { GNI } \\
\text { Per Capita } \\
\text { US\$ (1) } \\
\end{array}$ & $\begin{array}{c}\text { Agriculture Share } \\
\text { in GDP (1998) } \\
\% \quad(2) \\
\end{array}$ & $\begin{array}{c}\text { Agribusiness Share } \\
\text { in GDP } \\
\% \quad(3) \\
\end{array}$ & $(3) /(2)$ & Note \\
\hline Argentina & 8,230 & 5.60 & 32.20 & 5.75 & A \\
\hline Áustria & 27,040 & 2.50 & 5.70 & 2.28 & B \\
\hline Belgium-Luxembourg & 25,590 & 1.60 & 5.80 & 3.63 & $\mathrm{C}$ \\
\hline Brazil & 4,610 & 7.47 & 26.58 & 3.56 & D \\
\hline Canadá & 20,000 & 2.60 & 15.30 & 5.88 & $\mathrm{~B}$ \\
\hline Chile & 4,890 & 8.50 & 32.10 & 3.78 & A \\
\hline Colombia & 2,410 & 14.30 & 32.10 & 2.24 & A \\
\hline Costa Rica & 3,590 & 12.80 & 32.50 & 2.54 & A \\
\hline Denmark & 32,770 & 2.90 & 11.10 & 3.83 & B \\
\hline Finland & 24,750 & 3.60 & 10.70 & 2.97 & B \\
\hline France & 24,770 & 3.20 & 8.50 & 2.66 & B \\
\hline Germany & 26,630 & 1.30 & 5.10 & 3.92 & $\mathrm{~B}$ \\
\hline Greece & 12,130 & 8.50 & 19.90 & 2.34 & $\mathrm{~B}$ \\
\hline Ireland & 20,630 & 4.90 & 16.20 & 3.31 & B \\
\hline Italy & 20,560 & 3.10 & 7.00 & 2.26 & B \\
\hline México & 4,020 & 5.20 & 24.50 & 4.71 & A \\
\hline Netherlands & 25,160 & 3.20 & 8.70 & 2.72 & A \\
\hline Peru & 2,210 & 9.00 & 31.80 & 3.53 & $\mathrm{~B}$ \\
\hline Portugal & 11,030 & 4.10 & 13.80 & 3.37 & B \\
\hline Spain & 14,840 & 4.40 & 10.60 & 2.41 & $\mathrm{~B}$ \\
\hline Sweden & 28,710 & 2.30 & 5.50 & 2.39 & B \\
\hline United Kingdom & 22,790 & 1.30 & 7.10 & 5.46 & B \\
\hline Uruguay & 6,620 & 7.00 & 34.80 & 4.97 & B \\
\hline USA & 30,700 & 1.60 & 8.10 & 5.06 & A \\
\hline Venezuela & 3,540 & 5.10 & 20.50 & 4.02 & A \\
\hline Mean & 16,329 & 5.04 & 17.05 & 3.58 & \\
\hline Standard Deviation & 10,398 & 3.45 & 10.62 & 1.16 & \\
\hline Minimum & 2,210 & 1.30 & 5.10 & 2.24 & \\
\hline Maximum & 32,770 & 14.30 & 34.80 & 5.88 & \\
\hline Median & 20,000 & 4.10 & 13.80 & 3.53 & \\
\hline Less 10,000 & 4,458 & 8.33 & 29.68 & 3.90 & \\
\hline$>=10,000<20,000$ & 12,667 & 5.67 & 14.77 & 2.71 & \\
\hline$>=20,000$ & 25,392 & 2.62 & 8.83 & 3.57 & \\
\hline
\end{tabular}

Source: IADB (2003), World Bank (2004), van Leeuwen (2000), and research data.

Notes:

a - 1997

b - 1995

c - 1995, Agriculture data only for Belgium

d - 1999, data estimated by the author

e - GNI per capita, Atlas method (current US\$) 1998 


\subsection{Agribusiness in the Brazilian States}

This section presents the results for the Brazilian agribusiness, which are displayed into Tables 2 to 6 . Figure 1 presents a map of Brazil, such that it is possible to locate every region and state in its geographical position in the country.

From the data presented in Table 2 it can be seen the uneven distribution of income among the Brazilian states and macro regions. The richest region is the Southeast region, with a per capita income $34 \%$ over the Brazilian average, and which concentrates $56.7 \%$ of the Brazilian GDP, $42.6 \%$ of its population, and $45.4 \%$ of the agribusiness GDP. It is followed by the South region, with a per capita income $21 \%$ over the Brazilian average, and with a share of $18.1 \%$ of the Brazilian GDP, $14.9 \%$ of its population, and $28.1 \%$ of the agribusiness GDP. The Central West region has a per capita income that is $15 \%$ over the Brazilian average, mainly because of the Federal Districted where the Brazilian capital (Brasília), with a per capita income three times bigger than the national average, is located. As a result of the above the Central West region has a share of $7.8 \%$ of the Brazilian GDP, $6.8 \%$ of its population, and $8.1 \%$ of the agribusiness GDP. The North region has a per capita income $37 \%$ below the Brazilian average, and a share of $4.7 \%$ of the Brazilian GDP, $7.4 \%$ of its population, and $5.7 \%$ of the agribusiness GDP. And finally, the Northeast region has a per capita income 56\% below the Brazilian average, and a share of $12.5 \%$ of the Brazilian GDP, $28.2 \%$ of its population, and $12.7 \%$ of the agribusiness GDP.

In economic terms, the more developed state in Brazil, outside the Federal District (mainly a public sector economy), is the São Paulo state, which accounts for $34.50 \%$ of the Brazilian GDP, $21.9 \%$ of the Brazilian population, $28.7 \%$ of the agribusiness GDP, and a per capita income 58\% bigger than the national average. The productive structure of the state also shows as the more developed in the nation.

Considering the importance of the agribusiness GDP relatively to the importance of the economy GDP (Table 3), the results show that the agribusiness, relatively, is less important for the Southeast region than for the other regions, despite the fact that the biggest share of the agribusiness is in this region. 
Figure 1: Map of the Brazilian States and Macro Regions

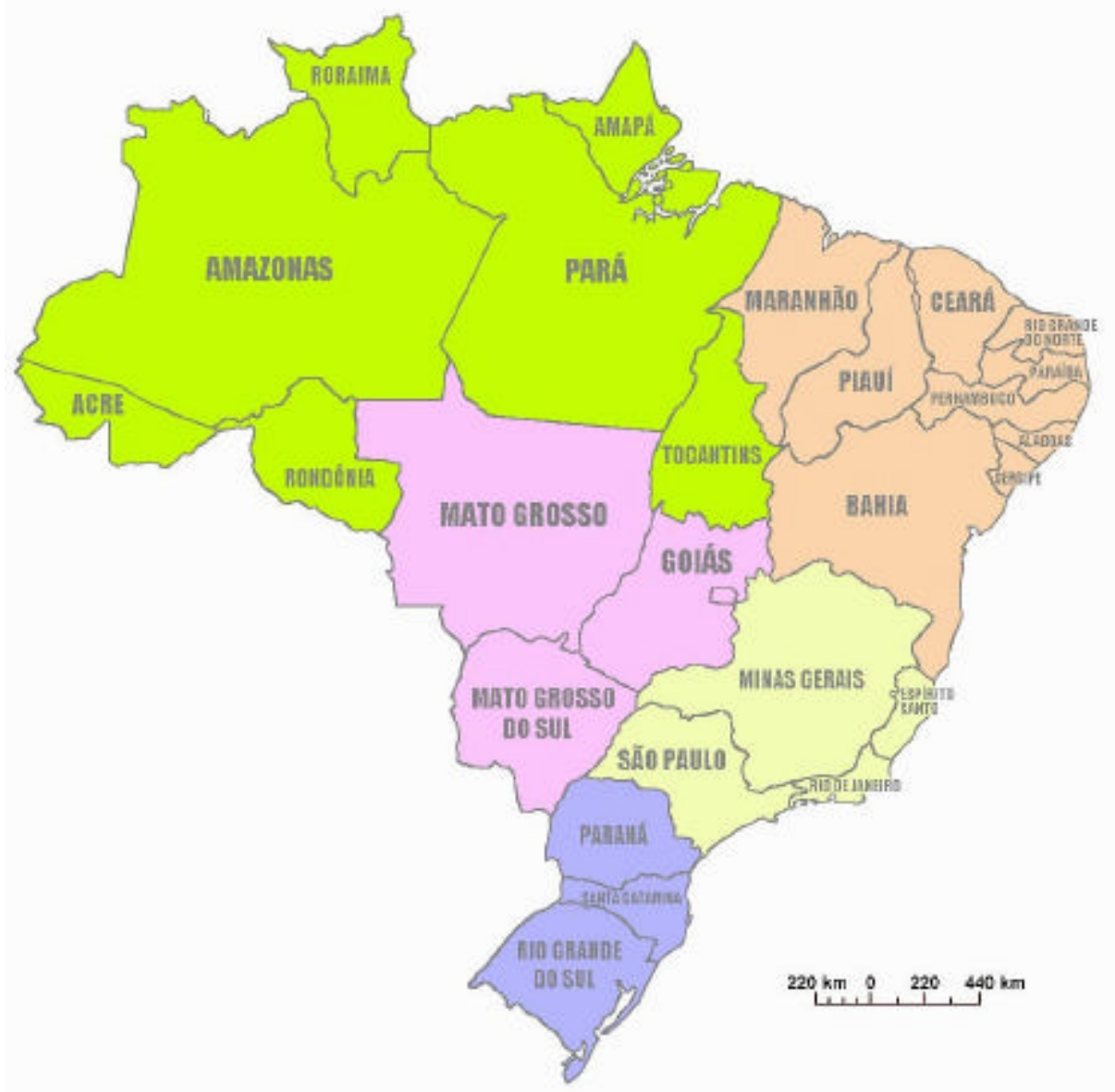


Table 2. GDP, Population, GDP Per Capita, and Agribusiness GDP for Brazilian States, Macro Regions, and the Whole Economy - 1999

\begin{tabular}{|c|c|c|c|c|}
\hline & $\begin{array}{c}\text { GDP } \\
\text { US\$ Million }\end{array}$ & $\begin{array}{c}\text { Population } \\
\text { Thousand }\end{array}$ & $\begin{array}{c}\text { Per Capita GDP } \\
\text { US\$ }\end{array}$ & $\begin{array}{l}\text { Agribusiness GDP } \\
\text { US\$ Million }\end{array}$ \\
\hline North & 24,950 & 12,134 & 2,056 & 7,996 \\
\hline Acre & 865 & 528 & 1,639 & 174 \\
\hline Amapá & 905 & 440 & 2,058 & 115 \\
\hline Amazonas & 9,566 & 2,581 & 3,706 & 1,385 \\
\hline Pará & 9,299 & 5,886 & 1,580 & 4,719 \\
\hline Rondônia & 2,759 & 1,297 & 2,128 & 1,045 \\
\hline Roraima & 448 & 267 & 1,679 & 48 \\
\hline Tocantins & 1,107 & 1,135 & 976 & 510 \\
\hline Northeast & 66,569 & 46,289 & 1,438 & 17,940 \\
\hline Alagoas & 3,385 & 2,713 & 1,248 & 1,305 \\
\hline Bahia & 22,279 & 12,993 & 1,715 & 5,398 \\
\hline Ceará & 10,071 & 7,107 & 1,417 & 2,429 \\
\hline Maranhão & 4,285 & 5,418 & 791 & 1,724 \\
\hline Paraíba & 4,131 & 3,376 & 1,224 & 1,391 \\
\hline Pernambuco & 13,297 & 7,581 & 1,754 & 3,157 \\
\hline Piauí & 2,419 & 2,734 & 885 & 821 \\
\hline Rio Grande do Norte & 3,941 & 2,655 & 1,485 & 608 \\
\hline Sergipe & 2,762 & 1,713 & 1,613 & 1,106 \\
\hline Central West & 41,633 & 11,221 & 3,710 & 11,495 \\
\hline Federal District & 19,547 & 1,970 & 9,923 & 603 \\
\hline Goiás & 9,557 & 4,849 & 1,971 & 3,926 \\
\hline Mato Grosso & 6,469 & 2,376 & 2,723 & 3,257 \\
\hline Mato Grosso do Sul & 6,061 & 2,027 & 2,991 & 3,709 \\
\hline Southeast & 302,137 & 69,858 & 4,325 & 64,103 \\
\hline Espírito Santo & 9,528 & 2,938 & 3,243 & 3,276 \\
\hline Minas Gerais & 51,349 & 17,296 & 2,969 & 13,404 \\
\hline Rio de Janeiro & 58,004 & 13,807 & 4,201 & 6,919 \\
\hline São Paulo & 183,256 & 35,817 & 5,116 & 40,505 \\
\hline South & 95,845 & 24,446 & 3,921 & 39,667 \\
\hline Paraná & 34,706 & 9,376 & 3,702 & 12,846 \\
\hline Santa Catarina & 19,988 & 5,098 & 3,920 & 9,814 \\
\hline Rio Grande do Sul & 41,152 & 9,972 & 4,127 & 17,006 \\
\hline Brazil & $\mathbf{5 3 1 , 1 3 5}$ & 163,948 & 3,240 & 141,201 \\
\hline
\end{tabular}

Source: Research Data 
For 15 out of the Brazilian 27 states, the agribusiness has a bigger dimension than the other activities in the economy. i.e., the state agribusiness share in the Brazilian agribusiness is greater than its share in the Brazilian GDP (Table 3). Inside each one these states it is possible to measure the importance of the agribusiness for its economy (Table 4), the results show that the agribusiness has a share of more than $33 \%$ of these states GDP. These states are (agriculture and agribusiness share in the State GDP in parenthesis): Espírito Santo (7.5\% and 34.4\%), Paraná (13.0\% and 37.0\%), Santa Catarina (12.9\% and 49.1\%), Rio Grande do Sul (12.6\% and 41.3\%), Goiás (16.0\% and 41.1\%), Mato Grosso (21.0\% and 50.3\%), Mato Grosso do Sul (28.4\% and $61.2 \%$ ), Pará (23.5\% and 50.8\%), Rondônia (16.7\% and 37.9\%), Tocantins (18.3\% and $46.0 \%)$, Alagoas (8.2\% and 38.6\%), Maranhão (17.2\% and 40.2\%), Paraíba (11.1\% and 33.7\%), Piauí (9.1\% and $33.9 \%)$, and Sergipe (7.8\% and $40.1 \%)$.

The multiplier power of the agriculture, going to the agribusiness concept, in the Brazilian states goes from 2.2 to 14.8, a bigger spectrum than the one found for the selected countries presented into table one. However, the minimum multiplier power is similar to the one found for these countries.

The results for the Brazilian economy also shows that when studying the importance of the agriculture/agribusiness in a given re gion it is extremely important to take into consideration the regional differences, if this is not done, an overall economic policy for the country as a whole can have as a consequence some unexpected and undesired results.

Following the tendency observed for the countries presented in this study, as the per capita income increases, there is a tendency for a decrease in the share of the agriculture and the agribusiness in the economy GDP. This can lead one to think about the role that the agribusiness should play in a given economy.

Should the agribusiness be promoted as the leading sector in a given economy, or should it be used as the bases for the growth of the other sector s in the economy as it has been used in the past? 
Table 3. States and Macro Regions Shares in GDP and Agribusiness GDP, Brazil - 1999

\begin{tabular}{|c|c|c|c|}
\hline & $\begin{array}{c}\text { GDP } \\
\text { Shares }(\%) \\
\quad(1)\end{array}$ & $\begin{array}{c}\text { Agribusiness Shares } \\
(\%) \\
(2)\end{array}$ & $\begin{array}{c}(2) /(1) \\
(3)\end{array}$ \\
\hline North & 4.70 & 5.66 & 1.21 \\
\hline Acre & 0.16 & 0.12 & 0.76 \\
\hline Amapá & 0.17 & 0.08 & 0.48 \\
\hline Amazonas & 1.80 & 0.98 & 0.54 \\
\hline Pará & 1.75 & 3.34 & 1.91 \\
\hline Rondônia & 0.52 & 0.74 & 1.42 \\
\hline Roraima & 0.08 & 0.03 & 0.40 \\
\hline Tocantins & 0.21 & 0.36 & 1.73 \\
\hline Northeast & 12.53 & 12.71 & 1.01 \\
\hline Alagoas & 0.64 & 0.92 & 1.45 \\
\hline Bahia & 4.19 & 3.82 & 0.91 \\
\hline Ceará & 1.90 & 1.72 & 0.91 \\
\hline Maranhão & 0.81 & 1.22 & 1.51 \\
\hline Paraíba & 0.78 & 0.99 & 1.27 \\
\hline Pernambuco & 2.50 & 2.24 & 0.89 \\
\hline Piauí & 0.46 & 0.58 & 1.28 \\
\hline Rio Grande do Norte & 0.74 & 0.43 & 0.58 \\
\hline Sergipe & 0.52 & 0.78 & 1.51 \\
\hline Central West & 7.84 & 8.14 & 1.04 \\
\hline Federal District & 3.68 & 0.43 & 0.12 \\
\hline Goiás & 1.80 & 2.78 & 1.55 \\
\hline Mato Grosso & 1.22 & 2.31 & 1.89 \\
\hline Mato Grosso do Sul & 1.14 & 2.63 & 2.30 \\
\hline Southeast & 56.89 & 45.40 & 0.80 \\
\hline Espírito Santo & 1.79 & 2.32 & 1.29 \\
\hline Minas Gerais & 9.67 & 9.49 & 0.98 \\
\hline Rio de Janeiro & 10.92 & 4.90 & 0.45 \\
\hline São Paulo & 34.50 & 28.69 & 0.83 \\
\hline South & 18.05 & 28.09 & 1.56 \\
\hline Paraná & 6.53 & 9.10 & 1.39 \\
\hline Santa Catarina & 3.76 & 6.95 & 1.85 \\
\hline Rio Grande do Sul & 7.75 & 12.04 & 1.55 \\
\hline Brazil & 100.00 & 100.00 & 1.00 \\
\hline
\end{tabular}


Table 4. Agriculture and Agribusiness Shares in the States and Macro Regions GDP, Brazil - 1999

\begin{tabular}{|c|c|c|c|}
\hline & $\begin{array}{c}\text { Agriculture Share } \\
\text { in GDP }(\%) \\
(1)\end{array}$ & $\begin{array}{c}\text { Agribusiness Share } \\
\text { in GDP (\%) } \\
\text { (2) }\end{array}$ & $\begin{array}{c}(2) /(1) \\
(3)\end{array}$ \\
\hline North & 12.70 & 32.05 & 2.52 \\
\hline Acre & 4.54 & 20.11 & 4.43 \\
\hline Amapá & 5.02 & 12.71 & 2.53 \\
\hline Amazonas & 2.24 & 14.48 & 6.48 \\
\hline Pará & 23.54 & 50.75 & 2.16 \\
\hline Rondônia & 16.72 & 37.88 & 2.27 \\
\hline Roraima & 4.02 & 10.64 & 2.64 \\
\hline Tocantins & 18.28 & 46.03 & 2.52 \\
\hline Northeast & 8.18 & 26.95 & 3.29 \\
\hline Alagoas & 8.17 & 38.55 & 4.72 \\
\hline Bahia & 8.53 & 24.23 & 2.84 \\
\hline Ceará & 5.31 & 24.12 & 4.54 \\
\hline Maranhão & 17.16 & 40.24 & 2.34 \\
\hline Paraíba & 11.13 & 33.68 & 3.03 \\
\hline Pernambuco & 7.33 & 23.74 & 3.24 \\
\hline Piauí & 9.13 & 33.94 & 3.72 \\
\hline Rio Grande do Norte & 3.23 & 15.44 & 4.78 \\
\hline Sergipe & 7.78 & 40.05 & 5.15 \\
\hline Central West & 11.22 & 27.61 & 2.46 \\
\hline Federal District & 0.32 & 3.09 & 9.74 \\
\hline Goiás & 15.99 & 41.08 & 2.57 \\
\hline Mato Grosso & 20.96 & 50.34 & 2.40 \\
\hline Mato Grosso do Sul & 28.44 & 61.19 & 2.15 \\
\hline Southeast & 4.66 & 21.22 & 4.55 \\
\hline Espírito Santo & 7.46 & 34.38 & 4.61 \\
\hline Minas Gerais & 9.19 & 26.10 & 2.84 \\
\hline Rio de Janeiro & 0.81 & 11.93 & 14.80 \\
\hline São Paulo & 4.47 & 22.10 & 4.94 \\
\hline South & 12.81 & 41.39 & 3.23 \\
\hline Paraná & 13.00 & 37.01 & 2.85 \\
\hline Santa Catarina & 12.87 & 49.10 & 3.81 \\
\hline Rio Grande do Sul & 12.61 & 41.33 & 3.28 \\
\hline Brazil & 7.47 & 26.58 & 3.56 \\
\hline Mean & 10.39 & 31.30 & 4.07 \\
\hline Median & 8.83 & 33.81 & 3.13 \\
\hline
\end{tabular}


This is not an easy question to answer and for sure it can not be answer in the scope of the presented work, however, the work being conducted here could shed some light in the role that the agriculture and the agribusiness should play in the development process of a given region.

The values and shares of each component of the agribusiness - (i) nonagricultural inputs, (ii) agriculture, (iii) industry, and (iv) distribution - are presented into Tables 5 and 6.

For Brazil as a whole, the share in the agribusiness of the non-agricultural inputs is of $4.6 \%$, the share of the agriculture is $28.1 \%$, while the shares of industry and distribution are respectively of $32.8 \%$ and $34.5 \%$. The results clearly show the importance of the industry and distribution, with a joint share of $67.3 \%$, for the agribusiness. However, this distribution is not uniform among the states and the difference is due, to a great point to, the level of industrialization in a given state.

For the more developed South and Southeast regions the industry share in the agribusiness is around $35 \%$, while for the other regions is between $20 \%$ and $30 \%$, i.e., $21 \%$ for the Central West region, and $25 \%$ and $30 \%$ for the North and Northeast region, respectively.

This is an indication of a low level of aggregation of value in the less developed regions of the country, giving an indication that there is a space for the economic growth in these regions through the implementation of processing units of agricultural goods.

A typical example of this process is the Agriculture Frontier Region of Brazil, represented by the Central West region (Brazilian Savanna). With the states of Goiás, Mato Grosso, and Mato Grosso do Sul, being recently the main producers of soybeans and cotton in Brazil. In these states the share of Industry is around 25\% for the state of Goiás and around $17 \%$ for the other two. At the same time the share of the agriculture is of $39 \%$ for Goiás, $42 \%$ for Mato Groso and $46 \%$ for Mato Grosso do Sul.

Concerning the use of non-agricultural inputs in the Agribusiness, its share varies from $2.35 \%$ to $9.71 \%$, being the average $4.8 \%$. 
Table 5. Agribusiness GDP Values (US\$ Million) of Its Components, in the States and Macro Regions, Brazil - 1999

\begin{tabular}{|c|c|c|c|c|c|c|c|}
\hline & $\begin{array}{l}\text { Agribus. } \\
\text { (1) }\end{array}$ & $\begin{array}{l}\text { Non Agr. } \\
\text { Inputs } \\
\text { (2) }\end{array}$ & (3) & $\begin{array}{c}\text { Industry } \\
\text { (4) }\end{array}$ & $\begin{array}{l}\text { Distrib. } \\
\text { (5) }\end{array}$ & $\begin{array}{l}\text { Agr. } \\
\text { Inputs } \\
\text { (in 3) } \\
\text { (6) }\end{array}$ & $\begin{array}{l}\text { Total } \\
\text { Inputs } \\
(2)+(6)\end{array}$ \\
\hline North & 7,996 & 335 & 3,169 & 1,965 & 2,526 & 430 & 765 \\
\hline Acre & 174 & 6 & 39 & 49 & 79 & 6 & 12 \\
\hline Amapá & 115 & 5 & 45 & 10 & 54 & 4 & 9 \\
\hline Amazonas & 1,385 & 134 & 214 & 753 & 284 & 25 & 159 \\
\hline Pará & 4,719 & 122 & 2,189 & 918 & 1,491 & 287 & 409 \\
\hline Rondônia & 1,045 & 35 & 461 & 175 & 374 & 81 & 116 \\
\hline Roraima & 48 & 3 & 18 & 4 & 23 & 5 & 7 \\
\hline Tocantins & 510 & 29 & 202 & 57 & 221 & 23 & 52 \\
\hline Northeast & 17,940 & 913 & 5,446 & 5,367 & 6,215 & 760 & 1,674 \\
\hline Alagoas & 1,305 & 69 & 277 & 470 & 490 & 42 & 111 \\
\hline Bahia & 5,398 & 352 & 1,901 & 1,440 & 1,705 & 251 & 603 \\
\hline Ceará & 2,429 & 125 & 535 & 943 & 827 & 79 & 204 \\
\hline Maranhão & 1,724 & 50 & 735 & 263 & 676 & 45 & 95 \\
\hline Paraíba & 1,391 & 71 & 460 & 358 & 503 & 61 & 132 \\
\hline Pernambuco & 3,157 & 132 & 975 & 951 & 1,099 & 123 & 255 \\
\hline Piauí & 821 & 39 & 221 & 266 & 296 & 72 & 110 \\
\hline Rio Grande do Norte & 608 & 27 & 127 & 234 & 220 & 29 & 56 \\
\hline Sergipe & 1,106 & 49 & 215 & 443 & 400 & 58 & 107 \\
\hline Central West & 11,495 & 648 & 4,669 & 2,371 & 3,806 & 895 & 1,543 \\
\hline Federal District & 603 & 51 & 62 & 167 & 322 & 9 & 61 \\
\hline Goiás & 3,926 & 251 & 1,528 & 982 & 1,165 & 329 & 580 \\
\hline Mato Grosso & 3,257 & 195 & 1,356 & 566 & 1,140 & 278 & 472 \\
\hline Mato Grosso do Sul & 3,709 & 151 & 1,723 & 655 & 1,179 & 279 & 430 \\
\hline Southeast & 64,103 & 3,336 & 14,090 & 22,986 & 23,691 & 1,950 & 5,286 \\
\hline Espírito Santo & 3,276 & 135 & 710 & 1,204 & 1,227 & 78 & 213 \\
\hline Minas Gerais & 13,404 & 584 & 4,718 & 3,986 & 4,115 & 741 & 1,325 \\
\hline Rio de Janeiro & 6,919 & 307 & 467 & 2,981 & 3,163 & 60 & 368 \\
\hline São Paulo & 40,505 & 2,310 & 8,193 & 14,815 & 15,187 & 1,072 & 3,381 \\
\hline South & 39,667 & 1,261 & 12,276 & 13,646 & 12,483 & 1,780 & 3,041 \\
\hline Paraná & 12,846 & 470 & 4,513 & 3,944 & 3,919 & 665 & 1,135 \\
\hline Santa Catarina & 9,814 & 231 & 2,573 & 4,187 & 2,823 & 393 & 624 \\
\hline Rio Grande do Sul & 17,006 & 560 & 5,191 & 5,514 & 5,741 & 723 & 1,282 \\
\hline Brazil & 141,201 & 6,494 & 39,650 & 46,335 & 48,722 & 5,816 & 12,309 \\
\hline Mean & $9,669,762$ & 442,559 & $2,775,223$ & $3,130,476$ & $3,321,504$ & 404,793 & 847,351 \\
\hline Median & $5,069,091$ & 233,221 & $1,130,071$ & $1,278,060$ & $1,747,236$ & 142,343 & 378,110 \\
\hline
\end{tabular}


Table 6. Agribusiness GDP Shares of Its Components, in the States and Macro Regions GDP (\%), Brazil - 1999

\begin{tabular}{|c|c|c|c|c|c|c|}
\hline & $\begin{array}{l}\text { Non Agr. } \\
\text { Inputs } \\
\text { (2) }\end{array}$ & $\begin{array}{c}\text { Agriculture } \\
\text { (3) }\end{array}$ & $\begin{array}{c}\text { Industry } \\
\text { (4) }\end{array}$ & $\begin{array}{c}\text { Distrib. } \\
\text { (5) }\end{array}$ & $\begin{array}{l}\text { Agr. Inputs } \\
\text { (in 3) } \\
\text { (6) }\end{array}$ & $\begin{array}{l}\text { Total } \\
\text { Inputs } \\
(2)+(6)\end{array}$ \\
\hline North & 4.19 & 39.64 & 24.58 & 31.60 & 5.38 & 9.57 \\
\hline Acre & 3.69 & 22.59 & 28.12 & 45.61 & 3.39 & 7.07 \\
\hline Amapá & 4.51 & 39.51 & 8.69 & 47.29 & 3.36 & 7.87 \\
\hline Amazonas & 9.71 & 15.44 & 54.38 & 20.47 & 1.80 & 11.50 \\
\hline Pará & 2.58 & 46.38 & 19.45 & 31.59 & 6.08 & 8.66 \\
\hline Rondônia & 3.36 & 44.14 & 16.71 & 35.79 & 7.76 & 11.12 \\
\hline Roraima & 6.00 & 37.81 & 7.90 & 48.30 & 9.45 & 15.45 \\
\hline Tocantins & 5.70 & 39.70 & 11.18 & 43.43 & 4.47 & 10.16 \\
\hline Northeast & 5.09 & 30.35 & 29.92 & 34.64 & 4.24 & 9.33 \\
\hline A lagoas & 5.28 & 21.20 & 36.00 & 37.51 & 3.21 & 8.49 \\
\hline Bahia & 6.53 & 35.22 & 26.67 & 31.58 & 4.64 & 11.17 \\
\hline Ceará & 5.14 & 22.03 & 38.81 & 34.03 & 3.26 & 8.40 \\
\hline Maranhão & 2.89 & 42.65 & 15.25 & 39.22 & 2.60 & 5.49 \\
\hline Paraíba & 5.07 & 33.06 & 25.72 & 36.15 & 4.39 & 9.46 \\
\hline Pernambuco & 4.19 & 30.87 & 30.13 & 34.81 & 3.91 & 8.09 \\
\hline Piauí & 4.71 & 26.89 & 32.36 & 36.03 & 8.73 & 13.44 \\
\hline R Grande do Norte & 4.47 & 20.91 & 38.50 & 36.12 & 4.81 & 9.28 \\
\hline Sergipe & 4.41 & 19.42 & 40.02 & 36.15 & 5.28 & 9.69 \\
\hline Central West & 5.64 & 40.62 & 20.62 & 33.11 & 7.79 & 13.43 \\
\hline Federal District & 8.51 & 10.27 & 27.77 & 53.46 & 1.55 & 10.06 \\
\hline Goiás & 6.39 & 38.92 & 25.01 & 29.68 & 8.39 & 14.78 \\
\hline Mato Grosso & 5.98 & 41.64 & 17.38 & 35.00 & 8.52 & 14.50 \\
\hline M ato Grosso do Sul & 4.08 & 46.47 & 17.67 & 31.78 & 7.52 & 11.59 \\
\hline Southeast & 5.20 & 21.98 & 35.86 & 36.96 & 3.04 & 8.25 \\
\hline Espírito Santo & 4.12 & 21.68 & 36.75 & 37.45 & 2.37 & 6.49 \\
\hline Minas Gerais & 4.36 & 35.20 & 29.74 & 30.70 & 5.53 & 9.89 \\
\hline Rio de Janeiro & 4.44 & 6.75 & 43.09 & 45.71 & 0.87 & 5.31 \\
\hline São Paulo & 5.70 & 20.23 & 36.58 & 37.49 & 2.65 & 8.35 \\
\hline South & 3.18 & 30.95 & 34.40 & 31.47 & 4.49 & 7.67 \\
\hline Para & 3.66 & 35.13 & 30.71 & 30.50 & 5.17 & 8.83 \\
\hline Santa Catarina & 2.35 & 26.22 & 42.67 & 28.77 & 4.00 & 6.35 \\
\hline Rio Grande do Sul & 3.29 & 30.52 & 32.43 & 33.76 & 4.25 & 7.54 \\
\hline Brazil & 4.60 & 28.08 & 32.82 & 34.51 & 4.12 & 8.72 \\
\hline Mean & 4.83 & 30.37 & 28.37 & 36.43 & 4.76 & 9.59 \\
\hline Median & 4.46 & 31.96 & 28.93 & 35.91 & 4.43 & 9.37 \\
\hline
\end{tabular}




\section{FINAL COMMENTS}

By analyzing the results presented in this paper, one can infer the complexity of the Brazilian economy and its agribusiness, with differences among regions and inside regions among states.

The Agribusiness results show the fundamental role that this segment has performed in the Brazilian economy, responsible for approximately $27 \%$ of its GDP in 1999. The results point out the importance and dependence of the other sectors of the economy in the agriculture, the share $₫ 7.5 \%$, in 1999 , of the Brazilian agriculture in the national GDP is multiplied approximately 3.6 times when the Agribusiness concept is used.

The Southeast region has a share of $56.9 \%$ of the Brazilian GDP and $45.4 \%$ of the Brazilian agribusiness, while the shares of the South region are respectively $18.1 \%$ and $28.1 \%$, for the Central West are $7.84 \%$ and $8.14 \%$, for the North $4.7 \%$ and $5.7 \%$, and for the Northeast $12.5 \%$ and $12.7 \%$. These results show that the agribusiness, relatively, is less important for the Southeast region than for the other regions, despite the fact that the biggest share of the agribusiness is in the Southeast region.

The share of each component of the Agribusiness - (i) non-agricultural inputs, (ii) agriculture, (iii) industry, and (iv) distribution - differs among the states and is to a certain point related with the level of industrialization in a given state.

For Brazil as a whole, the share in the agribusiness of the non-agricultural inputs is of $4.6 \%$, the share of the agriculture is $28.1 \%$, while the shares of industry and distribution are respectively of $32.8 \%$ and $34.5 \%$.

Despite the study made here, there are still some questions left out and that need to be uncovered, like, how to measure the contribution of the a given culture to the agribusiness, how the regions interact among themselves in generating the value of the agribusiness, how the agriculture can take advantage of this more advanced and integrated process of production, and what should be the future of the agriculture in this new integrated setting. 


\section{REFERENCES}

Davis, J. and Goldberg, R. (1957). A Concept of Agribusiness, Harvard University, Boston.

Furtuoso, M.C.O. (1998). O Produto Interno Bruto do Complexo Agroindustrial Brasileiro, Ph.D. Thesis, Universidade de São Paulo.

Furtuoso M.C.O., Barros, G.S.C., and Guilhoto, J.J.M. (1998). "The Gross National Production of the Brazilian Agroindustrial Complex", Brazilian Review of Agricultural Economics and Rural Sociology, vol. 36, pp. 9-31.

Furtuoso, M.C.O. e J.J.M. Guilhoto (2003). "Estimativa e Mensuração do Produto Interno Bruto do Agronegócio da Economia Brasileira, 1994 a 2000”. Revista Brasileira de Economia e Sociologia Rural. Vol 41, N. 4, Nov./Dez., pp. 803-827

Guilhoto, J.J.M., Furtuoso, M.C.O., and Barros, G.S.C. (2000). O Agronegócio na Economia Brasileira, 1994-1999, Research Report, CEPEA / CNA, Brasilia.

Guilhoto, J.J.M. et al. (2004). "Matriz de Interregional de Insumo-Produto da Economia Brasileira para 1999". Work in Progress. FEA-USP.

IADB (2003). "More Than Food on the Table: Agriculture's True Contribution to the Economy". Executive Summary. October $20^{\text {th }}$.

Leeuwen, M. van (2000). "Importance of Agro-Food Chains in EU Regions: a CrossSection Analysis.". Proceedings of the $13^{\text {th }}$ International Conference on Input-Output Techniques", August 21-25. Macerata. Italy.

Leontief, W. (1951). The Structure of the American Economy, 2nd edition, Oxford University Press, New York.

Pinazza, L.A. and Araújo, N.B. (1993). Agricultura Brasileira no Século XX: Uma Visão de Agribusiness, Globo, Rio de Janeiro.

SNA (1993). System of National Accounts. Rev. 4. Commission of the European Communities. Brussels.

World Bank (2004). World Bank Data by Country. In http://www.worldbank.org/data/countrydata/countrydata.html 